\title{
Agroforestry systems and understory harvest management: the impact on growth and productivity of dual-purpose wheat
}

\author{
BRAULIO O. CARON ${ }^{1}$, MARCOS VINÍCIUS M. PINHEIRO ${ }^{1}$, CLEITON KORCELSKI ${ }^{2}$, FELIPE \\ SCHWERZ ${ }^{3}$, ELVIS FELIPE ELLI' ${ }^{4}$, JAQUELINE SGARBOSSA ${ }^{1}$ and LILIANE B. TIBOLLA ${ }^{1}$
}

\author{
${ }^{1}$ Department of Agronomic and Environmental Sciences, Federal University of Santa Maria, Frederico Westphalen \\ Campus, Linha 7 de setembro, s/n, BR 386, Km 40, 98400-000 Frederico Westphalen, RS, Brazil \\ ${ }^{2}$ Agronomy/PPGAgro, Passo Fundo University, Av. Brasil Leste, 99052-900 Passo Fundo, RS, Brazil \\ ${ }^{3}$ Luiz de Queiroz College of Agriculture, University of São Paulo (ESALQ-USP), Department \\ of Plant Science, Avenida Pádua Dias, 11, 13418-900 Piracicaba, SP, Brazil \\ ${ }^{4}$ Luiz de Queiroz College of Agriculture, University of São Paulo (ESALQ-USP), Department of \\ Biosystems Engineering, Avenida Pádua Dias, 11, 13418-900 Piracicaba, SP, Brazil
}

Manuscript received on June 28, 2018; accepted for publication on October 26, 2018

\begin{abstract}
How to cite: CARON BO, PINHEIRO MVM, KORCELSKI C, SCHWERZ F, ELLI EF, SGARBOSSA J AND TIBOLLA LB. 2019. Agroforestry systems and understory harvest management: the impact on growth and productivity of dual-purpose wheat. An Acad Bras Cienc 91: e20180667. DOI 10.1590/0001-3765201920180667.
\end{abstract}

\begin{abstract}
The objective of the study was to evaluate the growth and production efficiency of forage-grain dual-purpose wheat in two arrangements and four agroforestry systems (Intercrop-I and Intercrop-II), as well as to evaluate crop management for the wheat crops in two planting seasons (Crop Season I-2014 and Crop Season II-2015. The experiment was conducted in a randomized complete block design, factorial scheme $7 \times 2 \times 2$, with seven cultivation systems Eucalyptus urophylla $\mathrm{x}$ Eucalyptus grandis IntercropII and Intercrop-I; Peltophorum dubium Intercrop-II and Intercrop-I; P. rigida Intercrop-I; S. parahyba Intercrop-I; a wheat monoculture with no tree species present; and two harvest management techniques (with and without harvesting of the forage species). Agroforestry systems generated shading for wheat plants, with a higher phyllochron and lower values of leaf area index of those individuals kept under trees with higher crown shading (non-deciduous trees) due to the lower transmissivity of solar radiation. The systems composed with Schizolobium parahyba in Intercrop-I and Parapiptadenia rigida in Intercrop-I provide a minor phyllochron to the wheat, resulting in a higher leaf area index and dry matter yield. Thus, the cultivation of tree species and dual-skilled agricultural crops, such as wheat, provides promising alternatives for the future use of land in tropical countries.
\end{abstract}

Key words: BRS Tarumã wheat, Conversion efficiency, Phyllochron, Triticum aestivum.

\section{INTRODUCTION}

Agroforestry systems are characterized by land use management in which trees are grown in

Correspondence to: Braulio Otomar Caron

E-mail: otomarcaron@yahoo.com.br

ORCid: https://orcid.org/0000-0002-6557-3294 combination with agricultural crops or pastures, and/or animals at the same time (Quinkenstein et al. 2009, Cardinael et al. 2017) to improve temporal resource capture among species (Artru et al. 2017), and thus, increase the efficiency of resource utilization (such as nutrients, light and water) (Nair et al. 2008). Historically, agroforestry 
systems have been widely implemented as a way of achieving agricultural sustainability and lowering the negative effects of agriculture (e.g. water pollution, biodiversity loss, desertification, erosion and soil degradation) without compromising crop productivity (Albrecht and Kandji 2003, Torralba et al. 2016, Artru et al. 2017). In addition, integrated cropping systems with trees, grasses and animal components on the same land, is a widely used tool for reducing the atmospheric concentrations of greenhouse gases (Ferreiro-Domínguez et al. 2016).

In agroforestry systems, the inclusion of shrubs and trees provides better forage and shade to animals, which reduces stress for grazing animal, as well as reduces water loss through soil evaporation (Cubillos et al. 2016). In this type of system, an increase in pasture production does not affect the biomass of trees when the level of nutrients and water is enough for both strata (López-Díaz et al. 2017). A major obstacle for the adoption of this system is a lack of quantitative knowledge regarding the performance of different crops as they compete for resources with trees (Artru et al. 2017).

Among the limiting factors in this system are the underground competition for water and solar radiation (Rivest et al. 2013), the latter being one of the primary limiting resources for agricultural crops grown in the understory of forest species. This is because trees induce a heterogeneous environment and influence the availability of solar radiation which alters the quantity and quality of incident solar radiation in the understory and impacts the physiology and morphology of crops (Artru et al. 2017). Many agronomic studies have demonstrated a systematic reduction in the final yield as the amount of shade increases; however, the intensity of the crop response depends on both the environmental conditions and shading characteristics (Artru et al. 2017).

Other factors influencing the shading of these systems include tree-row orientations, distance between rows and tree emergence and leaf senescence (Reynolds et al. 2007); which also affects the underground performance of agricultural crops (Wang et al. 2016). The proximity of trees is a key factor in crop performance, but little information is available on the spatial distribution and components of the species under tree influence in agroforestry systems (Wang et al. 2016).

In southern Brazil, one of the major limitations of livestock activity is the scarcity of forage in the period between autumn and early winter which leads to a decline in milk and meat production (Meinerz et al. 2012). Among the winter pastures, we highlight dual-purpose wheat (Triticum aestivum L.) which presents an appropriate cycle to enable one to two grazing in addition to grain harvesting (Santos et al. 2015). With the introduction of new dual-purpose wheat genotypes on the market, a wide field of agricultural experimentation was opened, and the growth and development of these crops gained popularity in research.

BRS Tarumã wheat is the most common genotype for dual-purpose management in the Central Depression of Rio Grande do Sul, due to its balance between forage and grain yield (Meinerz et al. 2012). Despite its popularity, data on animal production in areas with dual-purpose wheat are scarce, although grazing on this wheat has provided weight gains similar to those found in animals fed on oats and ryegrass pasture (Bartmeyer et al. 2011) which encourages studies for improved winter cereals for dual-purposes in production systems with crop and livestock integration (Santos et al. 2015).

Most microclimate variations that result in altered growth and development of understory species depend on the shade level resultant from the tree canopy (Righi et al. 2007). The level of shading is a consequence of the tree species and their leaf area index, tree canopy management, and population and spatial arrangement of trees. It is important to adopt a spacing between tree rows that 
allows the entry of light at levels appropriate for the growth of species in understory.

Several studies have demonstrated the environmental benefits of agroforestry systems when compared to conventional agricultural systems, and the present study aims to evaluate the efficiency of growth and productivity of dualpurpose wheatgrass for different tree shadings of agroforestry systems, as well as to evaluate crop management of the crop in two agricultural years.

\section{MATERIALS AND METHODS}

\section{SITE DESCRIPTION}

In order to analyze the meteorological variability of the agroforestry system, the experiment was carried out in two harvest (collection) periods, harvest I and II, between June and November 2014 and from May to October 2015, respectively, in the experimental area of the Federal University of Santa Maria, Frederico Westphalen campus, (Universidade Federal de Santa Maria campus Frederico Westphalen) Rio Grande do Sul, Brazil (272' 26 “S, 5325'43” W, 461.3 m altitude). The soil of the experimental area is classified as a shallow typical lithic eutrophic neosoil, with rock outcrops and reasonable natural fertility (Cunha et al. 2011).

The following tree species, approximately seven years old, were used in the agroforestry systems: Parapiptadenia rigida, Peltophorum dubium, Eucalyptus urophylla x Eucalyptus grandis, and Schizolobium parahyba (called P.rigida; P. dubium; Eucalyptus; S. Parahyba, respectively); being arranged in two arrangements of agroforestry systems: Intercrop-I ( $6 \mathrm{~m}$ between forages x 1,5 m between plants) and Intercrop-II (12 $\mathrm{m}$ between forages x 1,5 m between plants) (Figures 1 and 2).

The sowing of the dual-purpose wheat was carried out by seeding (100 kg ha-1) fields in June 2014 and May 2015, the cultivar BRS Tarumã was used, with a density of $350 \mathrm{~m}^{-2}$ plants. Due to the rainy season between May and April 2014, sowing was completed in the June of that year, and not in May, as it normally would be. Fertilization was carried out during three periods. On the sowing day, base fertilization with a 10-20-20 formulated fertilizer (NPK) was carried out at a dose of $250 \mathrm{~kg}$ $\mathrm{ha}^{-1}$. For the second instance, 15 days after wheat emergence at the full tillering stage, a treatment of urea cover fertilization ( $45 \%$ of $\mathrm{N}$ ) was performed at a dose of $100 \mathrm{~kg} \mathrm{ha}^{-1}$, following the methodology of Large (1954). In the third stage, replacement fertilization with urea at a dose of $50 \mathrm{~kg} \mathrm{ha}^{-1}$ was performed only for the experimental units which were to be harvesting for forage analysis.

The harvesting of the forage species was conducted when the plant reached an optimum resting point on the sigmoid curve of plant growth, which is to say, when senescence of the first basal leaves of the plant were observed (Voisin 1957, Yin et al. 2003); being this management carried out for crops I and II, in the following agroforestry systems: Eucalyptus in Intercrop-II; P. dubium in Intercrop-II and Intercrop-I; P.rigida Intercrop-I; S.parahyba Intercrop-I; and wheat in monoculture; and on October $10^{\text {th }}, 2014$ and September $22^{\text {nd }}$, 2015 for Eucalyptus Intercrop-I.

\section{DATA COLLECTION}

During the course of two wheat Crop Seasons (Crop Season I - June to November 2014 and Crop Season II - May to October 2015), there were 8 and 12 evaluation points of incident solar radiation, transmissivity, temperature and relative air humidity. For the Crop Season I, the evaluation dates were: August $19^{\text {th }}$ and $26^{\text {th }}$, September $08^{\text {th }}, 16^{\text {th }}$ and $23^{\text {rd }}$, October $2^{\text {nd }}, 14^{\text {th }}$ and $28^{\text {th }}, 2014$. For Crop Season II, evaluation dates were: June $12^{\text {th }}, 19^{\text {th }}$ and $26^{\text {th }}$, July $28^{\text {th }}$, August $14^{\text {th }}, 19^{\text {th }}$ and $25^{\text {th }}$, September $1^{\text {st }}, 15^{\text {th }}$ and $29^{\text {th }}$, and October $6^{\text {th }}$ and $20^{\text {th }} 2015$. A pyranometer (LI-COR 32164) coupled to a LI- 


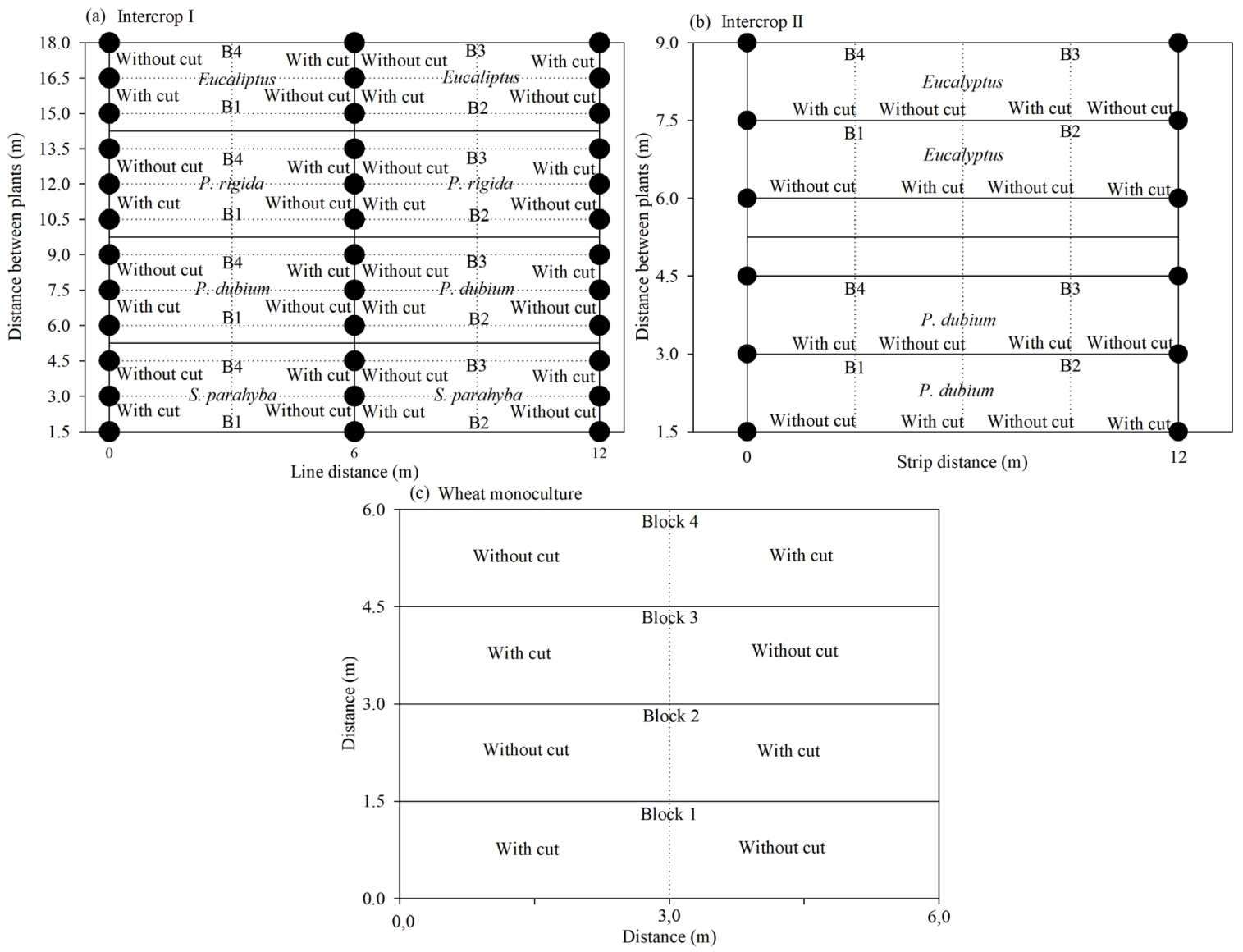

Figure 1 - Description of the sampling scheme for the agroforestry systems of two different spacings: (a) Intercrop-I (6 $\mathrm{m}$ between forages x $1.5 \mathrm{~m}$ between plants) and (b) Intercrop-II (12 m between forages x $1.5 \mathrm{~m}$ between plants); (c) dualpurpose wheat in monoculture. All systems with four blocks, and with or without grazing simulation (cut) dual-purpose wheat. Circles represent trees spaced 6 or 12 meters away.

$\mathrm{COR}^{\circledR} 1400$ model datalogger (solar radiation) and a thermohygrometer (relative air humidity and air temperature) were used to take measurements in the agroforestry systems. Three observations were made for each measurement, at distances of $0,1.5$ and 3 $\mathrm{m}$ from the trees to the Intercrop-I and 0,3 and 6 $\mathrm{m}$ distance from the tree to the Intercrop-II. For the monoculture three random locations were sampled.

We also collected continuous data for incident solar radiation $\left(\mathrm{MJ} \mathrm{m^{-2 }} \mathrm{h}^{-1}\right)$, rainfall $(\mathrm{mm})$ mean temperature $\left({ }^{\circ} \mathrm{C}\right)$ and relative humidity $(\%)$ of the INMET A854 automatic station of the $8^{\text {th }}$ DISME/INMET (Brazilian National Institute of Meteorology). During the experiment, average values for each observed meteorological variable was calculated; incident solar radiation on the vegetative canopy of the forage species was calculated from transmissivity.

\section{EXPERIMENTAL DESIGN FOR GROWTH AND PRODUCTIVITY VARIABLES}

The experiment was conducted in a randomized complete block design (RCDB), with a factorial scheme of $7 \times 2 \times 2$, with seven cultivation systems Eucalyptus Intercrop-II and Intercrop-I; P. dubium Intercrop-II and Intercrop-I; P. rigida Intercrop-I; S. parahyba Intercrop-I; and a wheat monoculture (with no tree species present), two harvest managements (with and without harvesting of the forage species), and two agricultural Crop Seasons (Crop Season I - June to November 2014 and 

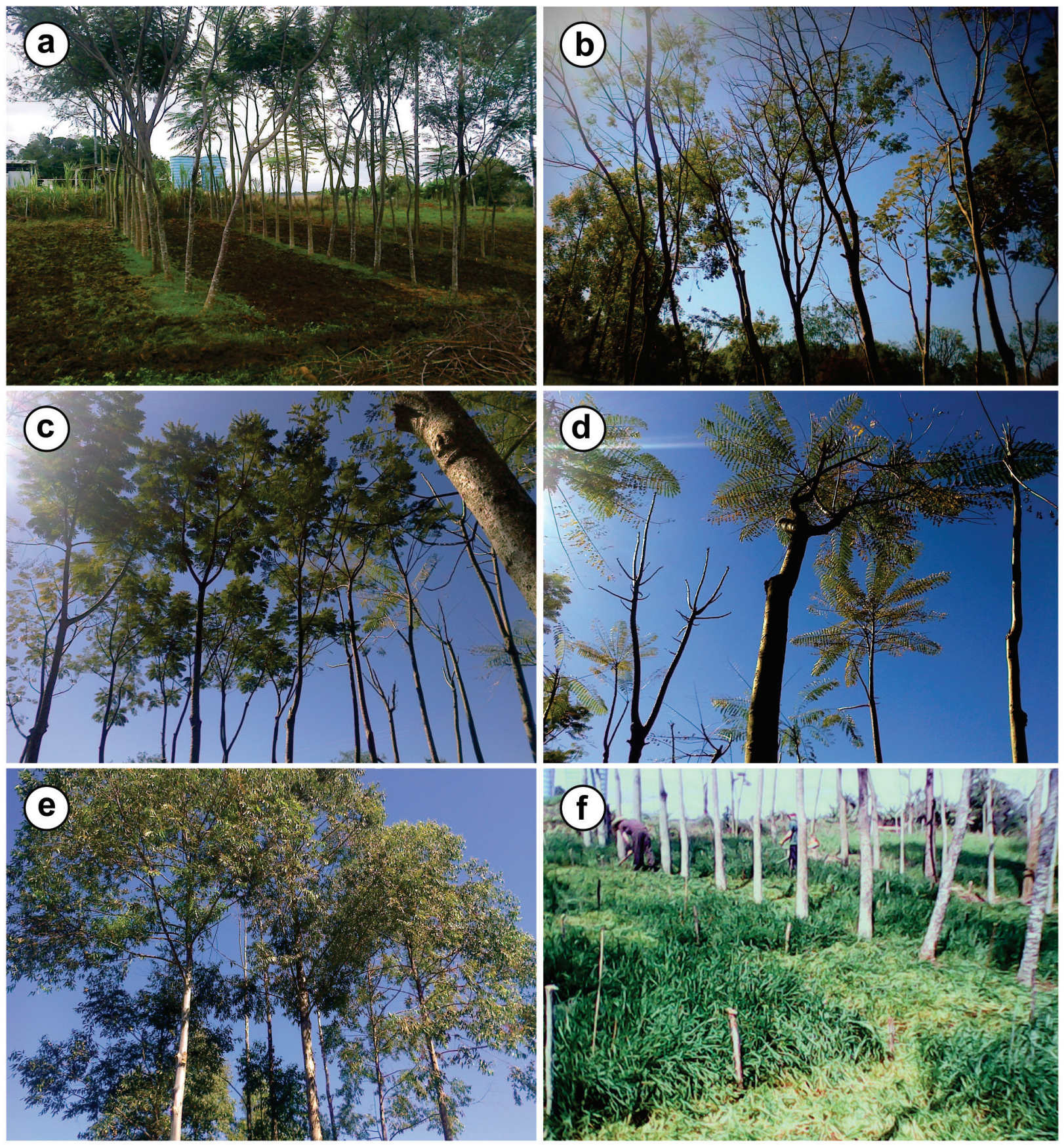

Figure 2 - Agroforestry system among seven years old tree species, with a spacing of 6 or 12 meters between trees, and double purpose wheat (Triticum aestivum) with or without grazing simulation (harvesting). Total area prepared for sowing of double purpose wheat (a); arboreous canopy of P.rigida (b), of P.dubium (c), of S.parahyba (d), of Eucalyptus (e), and simulation of double purpose wheat grazing (approximately $10 \mathrm{~cm}$ above the soil) consortium with P.dubium after three months of sowing (f). 
Crop Season II - May to October 2015), totaling 28 treatments with three replicates each. Due to the mortality of $P$. rigida and $S$. parahyba trees in Intercrop-II, it was not possible to study these cropping systems.

The analyzed variable were as follows: leaf area index (LAI) with three plants per replicate; total dry matter (TDM; $\mathrm{kg} \mathrm{ha}^{-1}$ ) from green plant matter collected in an area of $0.625 \mathrm{~cm}^{2}$ per replicate; grain yield $\left(\mathrm{kg} \mathrm{ha}^{-1}\right)$ collected at $1 \mathrm{~m}^{2}$ per replicate; and conversion efficiency of solar radiation $(\varepsilon b)$.

LAI was determined with the following equation:

$$
\mathrm{LAI}=\frac{\mathrm{LA}}{\mathrm{SA}}
$$

Where: LAI - leaf area index (dimensionless); LA - leaf area $\left(\mathrm{m}^{2}\right)$; SA - soil area used by the forage plant $\left(\mathrm{m}^{2}\right)$. Leaf area was determined by a leaf area determiner LI-COR model LI-3000.

To calculate the variable $\varepsilon b$, the following observations were used:

Transmissivity rate - observations were determined on the days of each dry matter harvest, which were performed between $11 \mathrm{am}$ and $12 \mathrm{pm}$. Subsequently, the averages for transmissivity of each agroforestry system was calculated $(100 \%$ transmissivity was used for the monoculture/ treeless system), using the following formula:

$$
\mathrm{T}=(\mathrm{Rn} / \mathrm{Rt}) * 100
$$

Where: $\mathrm{T}$ - rate of transmissivity (\%); Rn incident solar radiation beneath the canopy of the tree species $\left(\mathrm{W} \mathrm{m}^{-2}\right)$; Rt - solar radiation on the exterior of the vegetative canopy of the tree species $\left(\mathrm{W} \mathrm{m}^{-2}\right)$.

Intercepted photosynthetically active radiation (400-700 nm) was determined by the model proposed by Varlet-Grancher et al. (1989), as seen in the following formula:

$$
\text { PARi }=0.95^{*}(\text { PARinc }) *\left(1-\mathrm{e}^{\left(\mathrm{k}^{*} \text { LAI }\right)}\right)
$$

In which: PARi - photosynthetically active radiation intercepted $\left(\mathrm{MJ} \mathrm{m-}{ }^{2} \mathrm{~h}^{-1}\right)$; PARinc photosynthetically active radiation incident $\left(\mathrm{MJ} \mathrm{m}^{-2}\right.$ $\mathrm{h}^{-1}$ ); LAI - average leaf area index; $\mathrm{k}$ - coefficient of extinction of luminous (dimensionless). For the present study, the value of $\mathrm{k}$ used was 0.825 (Lunagaria and Shekh 2006).

Total dry matter (TDM) was obtained from the dry matter of the plant, in which green plant material was sampled in an area of $0.625 \mathrm{~m}^{2}$ per repetition. Sampling followed a methodology proposed by Fagundes et al. (1999) and Barro et al. (2008), and preceded drying at $45^{\circ} \mathrm{C}$ in a forced air ventilation oven until constant weight was reached. TDM was calculated using a model proposed by Monteith and Moss (1977) and the conversion efficiency of solar radiation ( $(\varepsilon)$ ), using the following formula:

$$
T D M=\varepsilon b^{*} P A R i
$$

Where: TDM - dry matter production $\left(\mathrm{g} \mathrm{m}^{-2}\right)$; PARi - accumulated photosynthetically active radiation intercepted $\left(\mathrm{MJ} \mathrm{m}^{-2}\right)$ and $\varepsilon \mathrm{b}$ in $\mathrm{g} \mathrm{MJ}^{-1}$.

\section{EXPERIMENTAL DESIGN FOR PHYLLOCHRON RELATED VARIABLES}

Due to the harvest management factor not being evaluated for the phyllochron variable $\left({ }^{\circ} \mathrm{C}\right.$ day $\left.^{-1}\right)$, CDB was performed in a $7 \times 2$ factorial scheme, with seven cultivation systems: Eucalyptus Intercrop-I and Intercrop-II; $P$. dubium Intercrop-I and Intercrop-II; P.rigida Intercrop-I; S.parahyba Intercrop-I; and two crops (Crop I - June to November 2014 and Crop II - May to October 2015), for a total of 14 treatments and three replications/treatment, and an experimental unit composed of three randomly selected wheat plants which were tagged and evaluated for each system.

To calculate the phyllochron, the following observations were used:

Foliar emission - To determine the index of Haun (IH) (Haun 1973), the length of the last and penultimate leaf emitted, and the number of leaves 
for three wheat plants randomly selected 35 days after sowing (DAS) were collected at intervals of twice weekly. To determine IH, the length of the last emerging leaf was used in the following equation:

$$
\mathrm{IH}=(\mathrm{CFem} / \mathrm{CFexp})+(\mathrm{N}-1)
$$

Where CFem - leaf length emergence; CFexp - fully expanded leaf length; $\mathrm{N}$ - total number of leaves on the plant.

The calculation for the daily thermal sum (STd; given in ${ }^{\circ} \mathrm{C}$ day $^{-1}$ ) was performed for the emission of a leaf (Gilmore Junior and Rogers 1958, Wilhelm and McMaster 1995, Streck et al. 2007). The thermal sum was calculated by the method proposed by Gilmore Junior and Rogers (1958). For this, the lower base temperature was considered to be $0^{\circ} \mathrm{C}$, optimum temperature $=22^{\circ} \mathrm{C}$ and upper base temperature $=35^{\circ} \mathrm{C}$, these are proposed by Alberto et al. (2010) for wheat cultivation. The STd was calculated from the emergence of wheat plants and resulted in the accumulated thermal sum (STa, in ${ }^{\circ} \mathrm{C}$ day), calculated by:

$$
\mathrm{STa}=\sum \mathrm{STd}
$$

Phyllochron was determined using the inverse of the linear regression coefficient between $\mathrm{IH}$ and STa (Xue et al. 2004).

The data for all variables were submitted to analysis of variance by the $\mathrm{F}$ test, to $5 \%$ of probability of error. LAI and TDM were evaluated in graphs with presence of average standard error bars, the phyllochron and $\varepsilon b$ variables were analyzed by regression $(p<0.05)$. The program SAS "Statistical Analysis System" was used.

\section{RESULTS}

By the analysis of variance, it was possible to observe a significant triple interaction between the factors cropping systems $\mathrm{x}$ crops $\mathrm{x}$ harvest management only for the grain yield variable. For the variables LAI, phyllochron, TDM and $\varepsilon$, there was a significant difference for the factors of cultivation system, crops and separate harvest managements $(p<0.05)$.

The average solar radiation flux was 17.8 and 13.8 $\mathrm{MJ} \mathrm{m}^{-2}$ day $^{-1}$, with an average air temperature of 18.4 and $17.8{ }^{\circ} \mathrm{C}$ and relative air humidity of 73.6 and $75.6 \%$, for the years 2014 and 2015, respectively. Among the evaluation years, the highest cumulative rainfall during the wheat development cycle was measured in 2014, with $898.2 \mathrm{~mm}$. However, this amount of precipitation occurred during a season which experienced prolonged periods of little rainfall; for example, $228.6 \mathrm{~mm}$ of rainfall was seen from September $28^{\text {th }}$ to $30^{\text {th }}, 2014$. In $2015,790.6 \mathrm{~mm}$ was measured, this amount of rainfall was more equally distributed throughout the wheat development cycle. It is important to mention the low values of relative humidity in the month of August 2015, mainly due to the lower rainfall which occurred in this period. These conditions led to the lengthening of the dualpurpose wheat development cycle, from 133 to 165 days (from 2014 to 2015), due to reductions in solar radiation flux and average air temperature, which reduced thermal accumulation (Figure 3).

It was possible to observe changes in the meteorological variables for the two harvests due to the greater occurrence of cloudy days in the year of 2015, resulting in smaller quantities of solar radiation and, consequently, lower air temperature and greater relative air humidity. For the year 2015, 87 cloudy days were observed, while in 2014 only 66 cloudy days were observed during the wheat development period.

Composting systems with Eucalyptus and $P$. dubium intercepted more solar radiation when compared to S.parahyba and P.rigida species. S.parahyba and P.rigida are deciduous species and result in greater incident solar radiation in undergrowth after tree-leaf senescence (Figure 2). Although P. dubium is deciduous, it was observed that its leaves began senescence later, when 

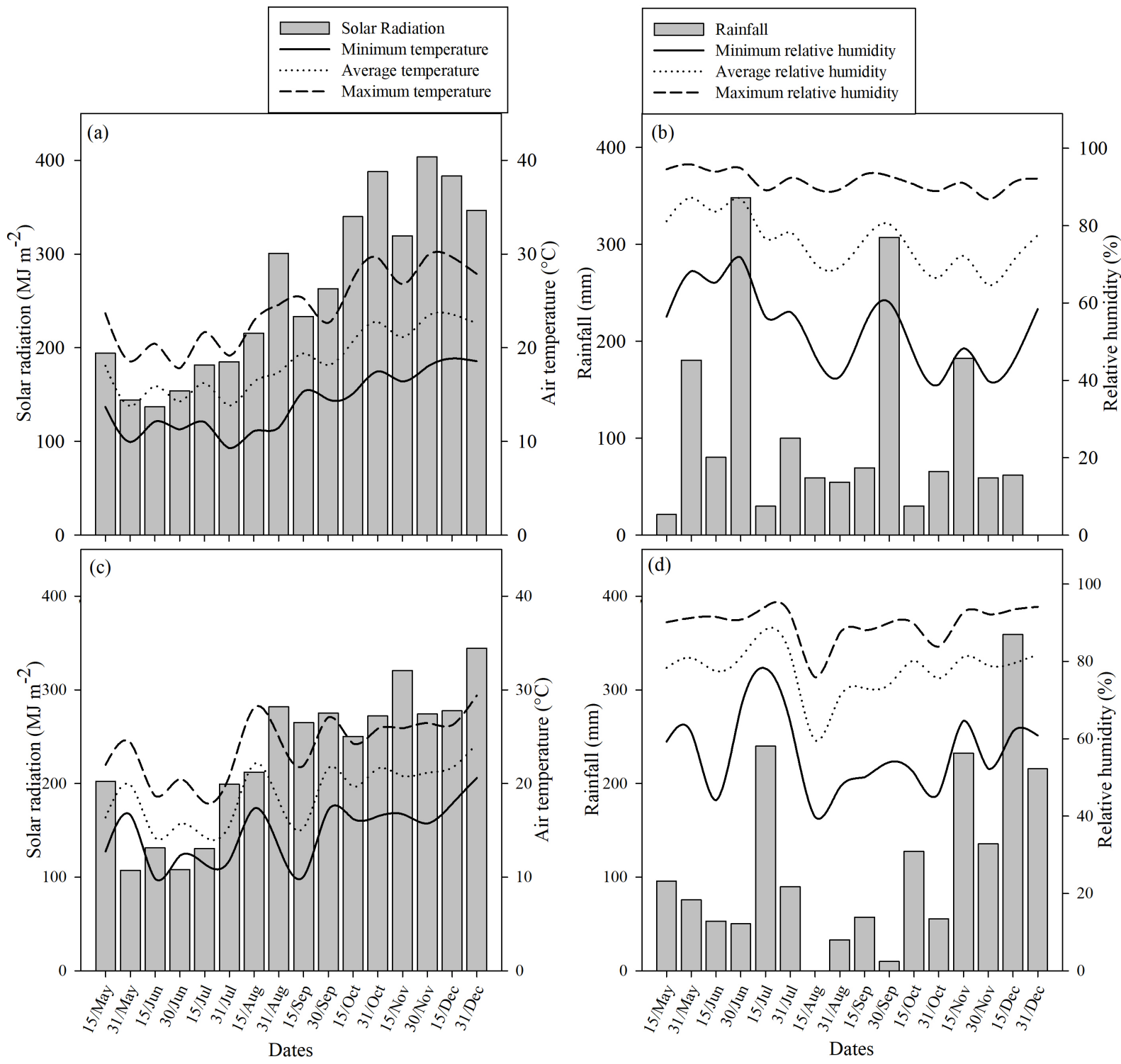

Figure 3 - Incident global solar radiation and air temperature (minimum, average and maximum), rainfall and relative humidity (minimum, average and maximum) for the two agricultural crop seasons, 2014 (a, b) and 2015 (c, d); Crop Season I was from June to November 2014 and Crop Season II from May to October 2015.

compared to the species S.parahyba and P.rigida. The canopies of S.parahyba and P.rigida trees had higher transmissivity averages when compared to Eucalyptus and P. dubium. It is noteworthy that from October 2014, all agroforestry systems presented transmissivities below or close to $50 \%$ (Figure 4). Due to the cold season during the initial phase of the study, the agroforestry system with S.parahyba Intercrop-I and P.rigida Intercrop-I had fewer leaves, allowing greater values of transmissivity.
After the cold season, these species obtained an increase in foliar area and, consequently, increased interception of the solar radiation and lower rates of transmissivity.

It was possible to observe that theinfluence of the agroforestry system encompasses the modification of the microclimate in the undergrowth, which changes, for example, meteorological elements such as air temperature and relative humidity. These both being dependent on solar radiation flux. In 

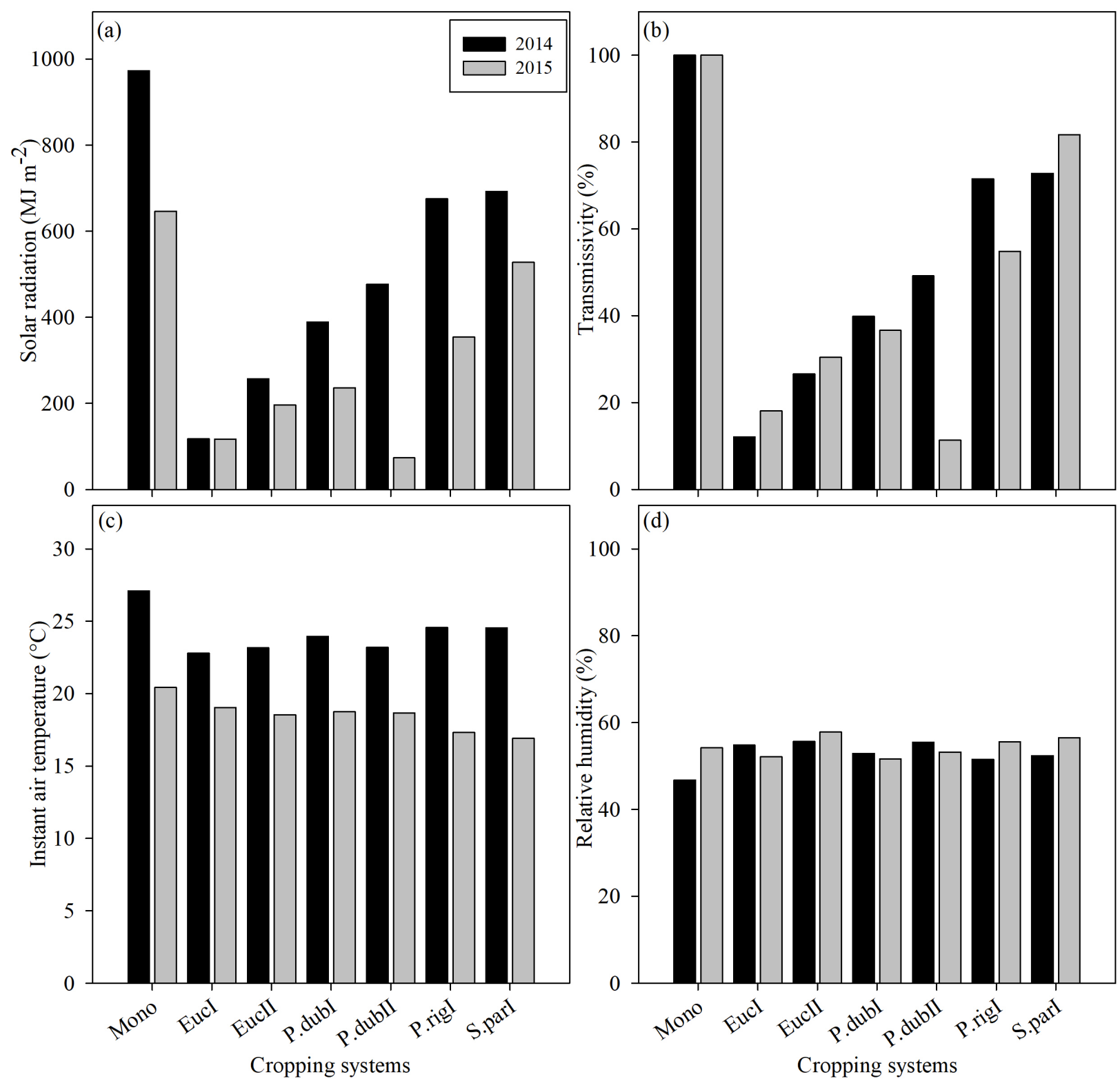

Figure 4 - Incident global solar radiation (a) transmissivity of solar radiation (b) air temperature (c) relative humidity (d) in different cropping systems in the crop years 2014 and 2015 (Crop Season I and II, respectively). Each bar represents an evaluation point. (Mono): Monoculture; (S.parI): Schizolobium parahyba in Intercrop-I; (P.rigI): Parapiptadenia rigida in Intercrop-I; (P.dubII): Peltophorum dubium in Intercrop-II; (P.dubI): Peltophorum dubium in Intercrop-I; (EucII): Eucalyptus urophylla $\mathrm{x}$ Eucalyptus grandis in Intercrop-II; (EucI): Eucalyptus urophylla $\mathrm{x}$ Eucalyptus grandis in Intercrop-I. Each bar was generated from the average of three daily values.

2015, within the agroforestry systems, the average values for instantaneous air temperature values were lower (Figure 4c) while relative humidity was higher (Figure 4d) when compared to the year 2014, which extended the cycle of development. Lower values of transmissivity were associated with lower values for air temperature and higher values for relative air humidity.

In Crop Season I (June to November 2014), lower values of phyllochron were observed in the wheat crop, mainly due to the higher available solar radiation flow and higher air temperature when 

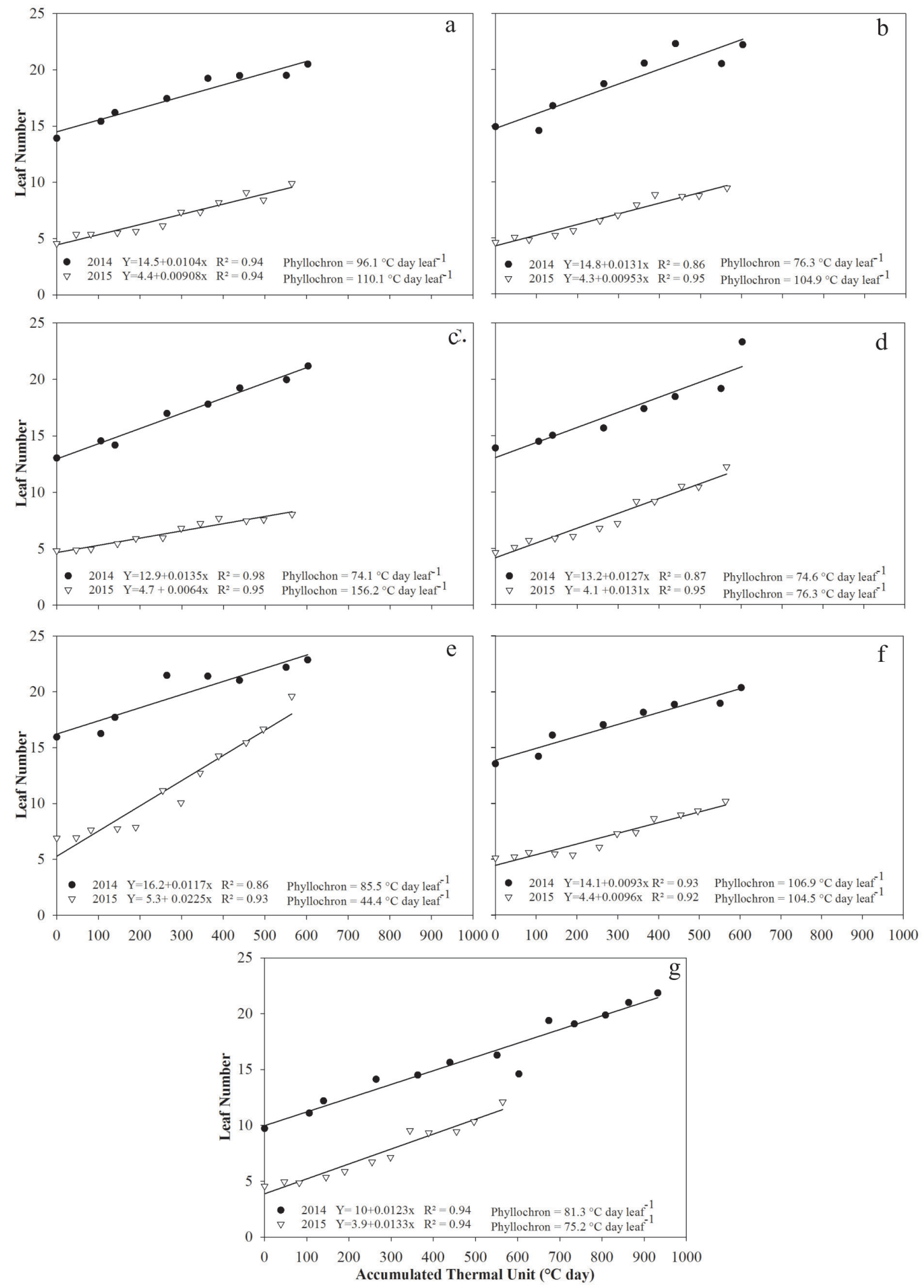

Figure 5 - Phyllochron $\left({ }^{\circ} \mathrm{C}\right.$ day leaf $\left.{ }^{1}\right)$ of dual-purpose wheat cultivated in different cropping systems: S.parahyba Intercrop-I (a); P.rigida Intercrop-I (b); P.dubium Intercrop-I (c); P.dubium Intercrop-II (d); Monoculture (e); Eucalyptus Intercrop-II (f); Eucalyptus Intercrop-I (g). 
compared to Crop Season II (May to October 2015), in which a significant increase of this variable was observed, due to a reduction of leaf emission. In Crop Season II, when wheat was cultivated in monoculture, a dramatic reduction in phyllochron was observed. In the two agricultural seasons, Crop Seasons I and II (June to November 2014 and May to October 2015), despite the distinction of time in days, similarities in the maximum number of leaves were observed in the plants grown in monoculture; this was not observed in the agroforestry systems for the two agricultural crops (Figure 5).

Despite obtaining the same number of leaves between the years of cultivation, the year of 2015 provided the lowest leaf emission, as evidenced by the lower values of LAI found in monoculture in that year. The highest amount of incident solar radiation observed in 2014 provided the highest LAI values, being higher when compared to Crop Season II (2015).

After the leaf reduction caused by the harvest management in the cropping systems, a greater increase in LAI values was observed, especially in those with the highest available solar radiation. Even after harvesting, wheat plants had a similar foliar emission as before the management, this was not equally observed for the plants submitted to the agroforestry systems such as Eucalyptus Intercrop-I and Intercrop-II, which resulted in lower LAI (Figure 6).

The greatest leaf emission found for wheat plants in agroforestry systems with greater incident solar radiation reflected higher TDM (Figure 7). When the dual-purpose wheat was subjected to shading in the S.parahyba Intercrop-I (Figure 7a) and P.rigida Intercrop-I (Figure 7b) and monoculture (Figure 7e), TDM values of 6,453 , 6,810 and $7,626 \mathrm{~kg} \mathrm{ha}^{-1}$ were observed, respectively. Such values are higher than those found in 2015, the crop season with lower incident solar radiation. When cultivated in a monoculture, it was possible to observe similar TDMs between Crop Seasons
I and II; however, the average daily increase in dry matter was lower in 2015. As the number of observed days increased, this difference became similar to what was observed in 2014 (Figure 7e).

It greater values of $\varepsilon b$ for the wheat plants were observed when cultivated in the Eucalyptus Intercrop-I system, which was superior when compared to the other cultivation systems. In the agroforestry systems S.parahyba Intercrop-I and P.rigida Intercrop-I, it was possible to observe the lowest values of $\varepsilon b$, which were comparable to wheat in monoculture (Figure 8a, $8 \mathrm{~b}$ and $8 \mathrm{e}$ ).

For grain yield, the monoculture wheat cultivation system was significantly higher in 2014 and 2015, regardless of the harvest management (with and without harvesting), and with an exception of S.parahyba Intercrop-I for 2015 with harvesting, did not differ $(p<0.05)$. For the two crops and all cultivation systems, it was possible to observe that the harvest management reduced grain yields (Table I).

\section{DISCUSSION}

This work describes, for the first time, the monitoring of the growth and productivity of dual-purpose wheat and the importance of the solar radiation and transmissivity in multiple agroforestry systems. And, it has been observed that the ideal cropping system is one in which deciduous plants are associated with agricultural crops. This is to avoid excessive shading for those crops grown in the understory, and thus allowing a more ideal transmission of incident solar radiation. Incident solar radiation becomes diffuse in these types of systems which can negatively impact the growth and productivity of plants grown in their understory; the success of agroforestry systems depends on the selection of shade tolerant species.

The average solar radiation flux was higher in 2014 than in 2015, however, the greatest value of transmissivity was observed in the year 2015. These 

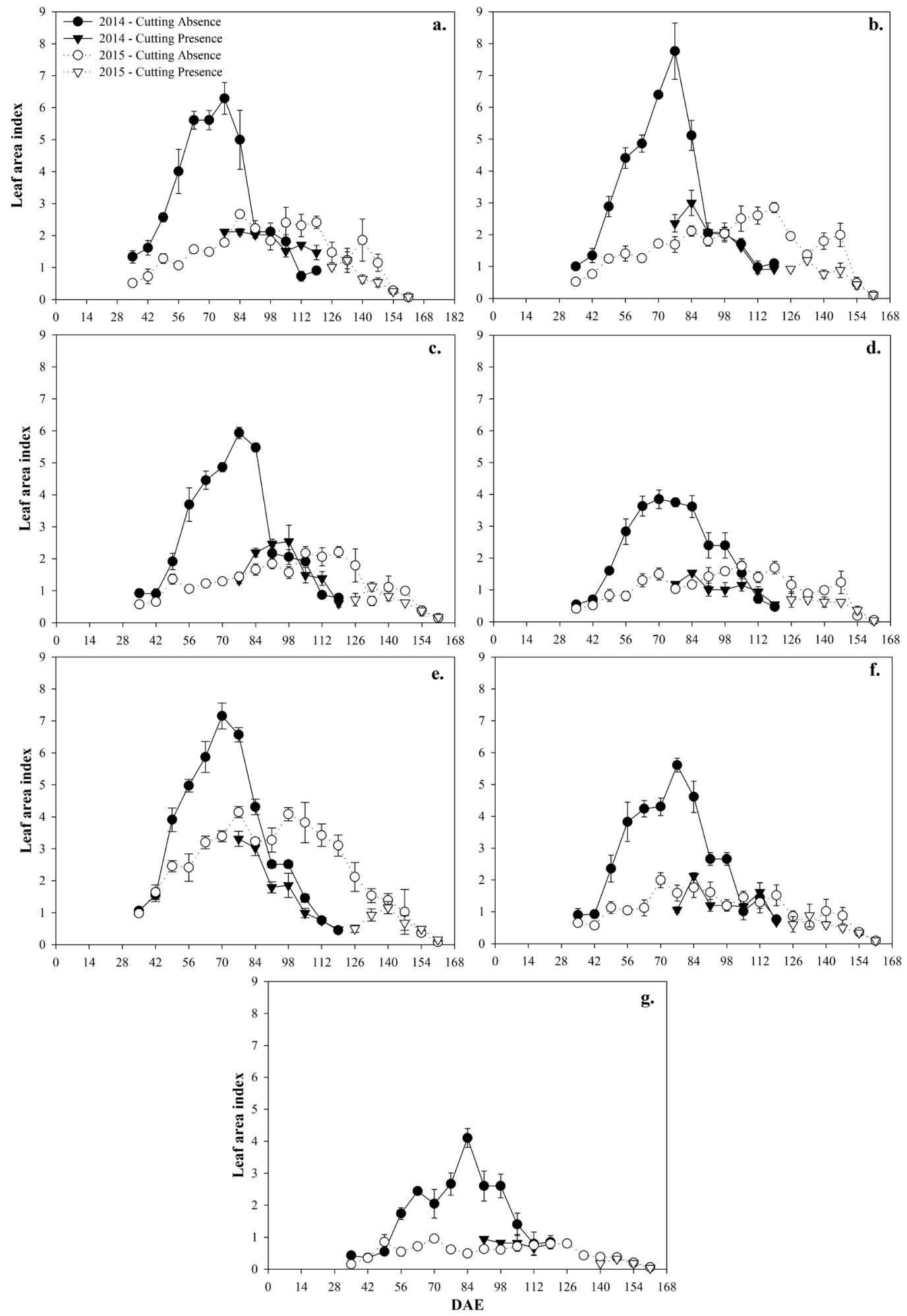

Figure 6 - Leaf area index (LAI) in days after emergency (DAE) dual-purpose wheat cultivated in different cropping systems and with or without a cut (grazing simulation) in the crop years of 2014 and 2015 (Crop Seasons I and II, respectively). S.parahyba Intercrop-I (a); P.rigida Intercrop-I (b); P.dubium Intercrop-I (c); and Intercrop-II (d); Monoculture (e); Eucalyptus Intercrop-I (f); e Intercrop-II (g). 

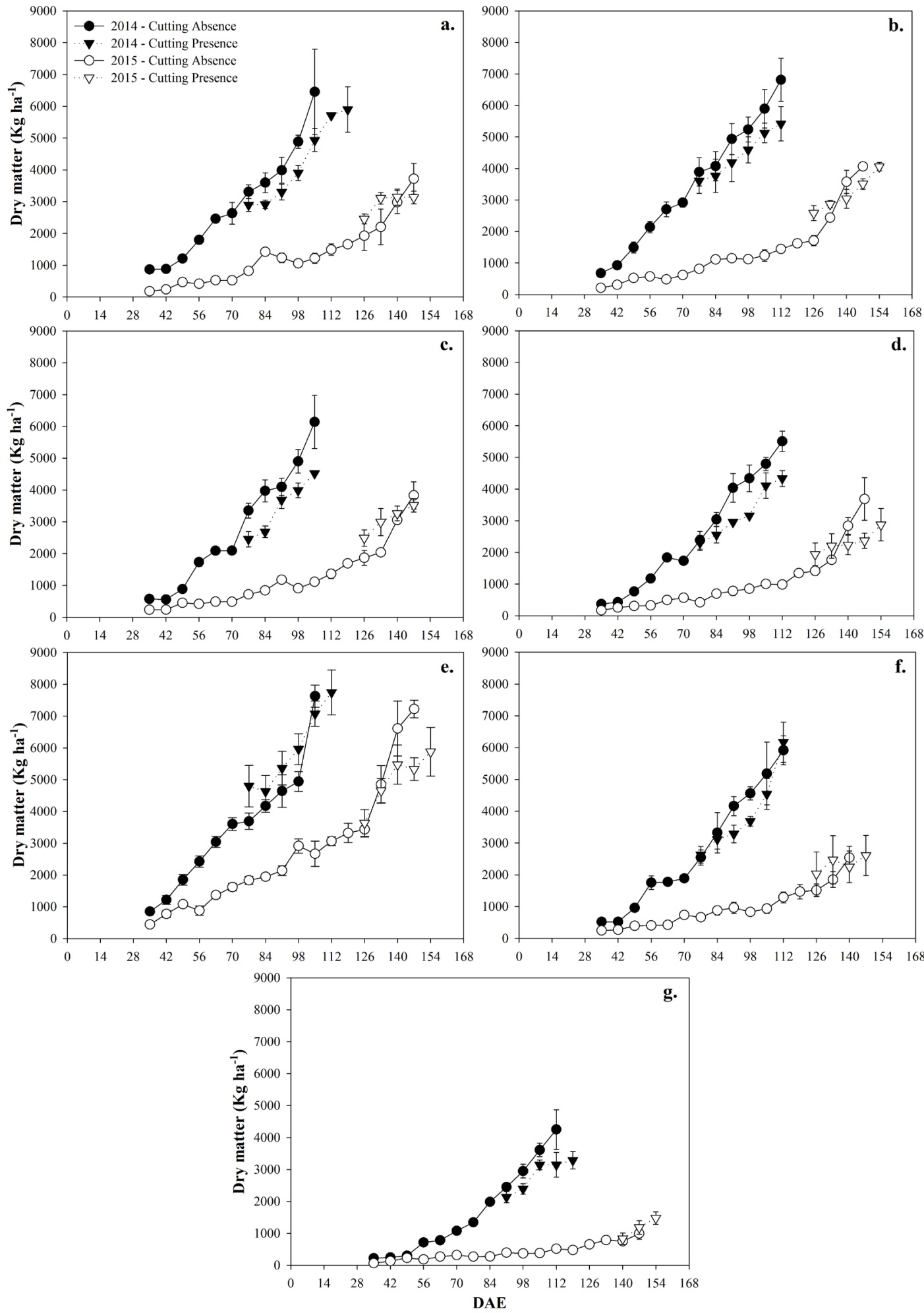

Figure 7 - Dry matter production (TDM) in days after the emergency (DAE) for dual-purpose wheat cultivated in different cropping systems and with or without a cut (grazing simulation) in the crop years of 2014 and 2015 (Crop Season I and II, respectively). S.parahyba Intercrop-I (a); P.rigida Intercrop-I (b); P.dubium Intercrop-I (c); and P.dubium Intercrop-II (d); Monoculture (e); Eucalyptus Intercrop-II (f); and Eucalyptus Intercrop-I (g). 
results are related to the inter-annual variation of solar radiation and the increase in seasonal cloud cover; this is a function of an increase in the fraction of diffuse, multidirectional incident radiation on the system. This can be seen as the result of the interaction of the direct radiation with the medium (Drechmer and Ricieri 2006).

In consortium crops where forest species are present, as in the case of agroforestry systems, there is a continuous growth in height, canopy projection and leaf area index, which alter the distribution of environmental resources over time (Müller et al. 2014), mainly solar radiation (Elli et al. 2016). The fraction of the solar radiation transmitted through the canopy, available for the plants in the understory is often present in mostly a diffuse form (Pezzopane et al. 2015). The increase in the proportion of diffuse incident radiation results in increases to the photosynthetic rates of the annual crop, due to the multidirectional solar radiation being absorbed with greater efficiency by leaves (Johnson and Smith 2006), and the efficiency in the interception of the radiation of plants in the understory. Thus, more efficient plants which intercept and absorb solar radiation will have a greater capacity for acclimatization and/or adaptation in agroforestry systems.

Lower solar radiation transmissivity in the canopy of the trees is often associated with lower values of air temperature and higher values of relative humidity. In the reduction of the solar radiation flux, observed inside the agroforestry systems of the present work, there was reduction of the air heating process by irradiation, which was reflected in a decline in air temperature. Valentini et al. (2010) observed that the greatest effects of the production system with the presence of the arboreal component were observed in the maximum air temperature, where a greater reduction in the values for the summer and spring seasons can be observed. Menezes et al. (2002) found reductions of $2,8^{\circ} \mathrm{C}$ in the maximum temperatures under canopies of Ziziphus joazeiro in relation to full sun Marin et al. (2006) observed increments up to $2^{\circ} \mathrm{C}$ at maximum air temperature at three meters distance from Gliricidia sepium trees when compared to measurements more near to the plant. The positive balance of photosynthesis is highly dependent on the plant respiration process. It is vital for the accumulation of carbohydrates and subsequent growth of the plant, and both processes are influenced by the air temperature in the environment (Sanchez 1995). In agroforestry systems, the main physiological process affected is photosynthesis; it is activated by the photosynthetically active radiation (RFAi) which is directly associated with the accumulation of dry matter production and is the main factor that conditions the growth of the plants (Caron et al. 2012).

Acclimatization of plant phenotypes depend on the growth environment (Casas et al. 2011), which makes complex growth assessment (Bundchen et al. 2015). For example Yoshida et al. (2011) reported that when growing tomato plants, in the absence of light, leaf emission was halted but resumed when again in the presence of solar radiation. In the present study, the reduction in incident solar radiation resulted in a lower phyllochron, suggesting that the lesser availability of solar radiation are conditions that influence the reduction in wheat leaf emission.

LAI restoration by plants is greater in plants that receive a higher intensity of solar radiation; this is due to the greater storage of energy sources in the roots, which lead to a greater re-sprouting capacity (Voisin 1957, Wang et al. 2009, Mielke and Schaffer 2010). Studies indicate that the low availability of solar radiation reduces the photosynthetic rate, directly reflecting the production and allocation of plant biomass in roots, stems and leaves (Wang et al. 2009, Mielke and Schaffer 2010); and under a consortium system (Triticum aestivum under Zizyphus jujuba trees) reductions occur in root length and total volume of produced wheat (Zhang 
et al. 2013). In the present work, the tree species presented distinct crowns which each uniquely affected the transmission of solar radiation. For example, in the P.rigida Intercrop-I and S.parahyba Intercrop-II culture systems, where higher transmissivity was observed, showed the greatest LAI values.

In addition, the years of cultivation were also significantly related to an increase of the leaf emission. In 2014 it was possible to observe a decrease in the wheat cycle, which influenced the greater leaf emission in a shorter period of time, and also grain yield (Table I), when compared to the year 2015; proving the hypothesis that solar radiation has an important influence on the physiological processes of plants. Using the tree species of Nothofagus antarctica, Bahamonde et al. (2014) also observed higher dry matter yields of different grasses under forests with higher rates of solar radiation transmissivity, stating that dry matter production of understory plants increases according to availability of solar radiation; and thus, the final yield of the crop varies between species levels and levels of shade (Artru et al. 2017).

In order to relate dry matter production to the amounts of incident solar radiation in the undergrowth, $\varepsilon b$ is a variable that indicates the energy used by the plant to produce and allocate dry matter. Some plants have the capacity to modify this efficiency when submitted to different levels of stress due to radiation deficit. In general, despite the fact that it presents a lower incidence of solar radiation, which presupposes an increase in wheat \&b, the year 2015 resulted in the the plants' low $\varepsilon b$ when compared to 2014. Thus, it can be assumed that $\varepsilon b$ is directly correlated to LAI for a cultivar. That is, LAI influences the interception of solar radiation, in which reflects the plant's dry matter production potential (Caron et al. 2012). In the present work, the low availability of solar radiation in shaded environments affected wheat production and the crop cycle; suggesting that plants grown in high shading environments reduce LAI and, consequently, reduce development (Caron et al. 2012).

Grain mass is directly related to the plant's capacity to accumulate or deposit reserves, and the reduction of incident solar radiation and low interception by the plant causes a reduction in grain yield (Fioreze and Rodrigues 2014). This is because the plant has two basic sources of assimilates: through the remobilization of assimilates stored temporarily in other organs of the plant, such as the stem, and directly from current photosynthesis. Considering that the transport of carbohydrates between the source (leaves and/or stem) and the drain (grain) involves a series of active metabolic processes, it is concluded that plants submitted to low levels of solar radiation tend to accumulate lesser amounts of dry matter in the grain.

The monocultures provided the highest grain yield, independent of the year and crop management, mainly due to the greater availability of solar radiation during the entire cycle. Incident solar radiation observed in 2014 for the S.parahyba and P.rigida systems in Intercrop-I were similar to monoculture in almost all the cycle (Figure 4), however, lower values were seen during the last three evaluations (including grain filling) which negatively influenced grain filling and, consequently, the final yield of the crop. This is explained by the low incidence of solar radiation, $\varepsilon b$, and LAI at the time of grain filling in these agroforestry systems.

Agroforestry systems have been proposed as a sustainable agricultural system when compared to conventional agriculture and silviculture; however forestry species should be chosen which do not compromise the productivity of the agricultural crop. The potential benefits of agroforestry systems are dependent upon contextual land use, and may depend on the interactions of multiple elements (Torralba et al. 2016). 

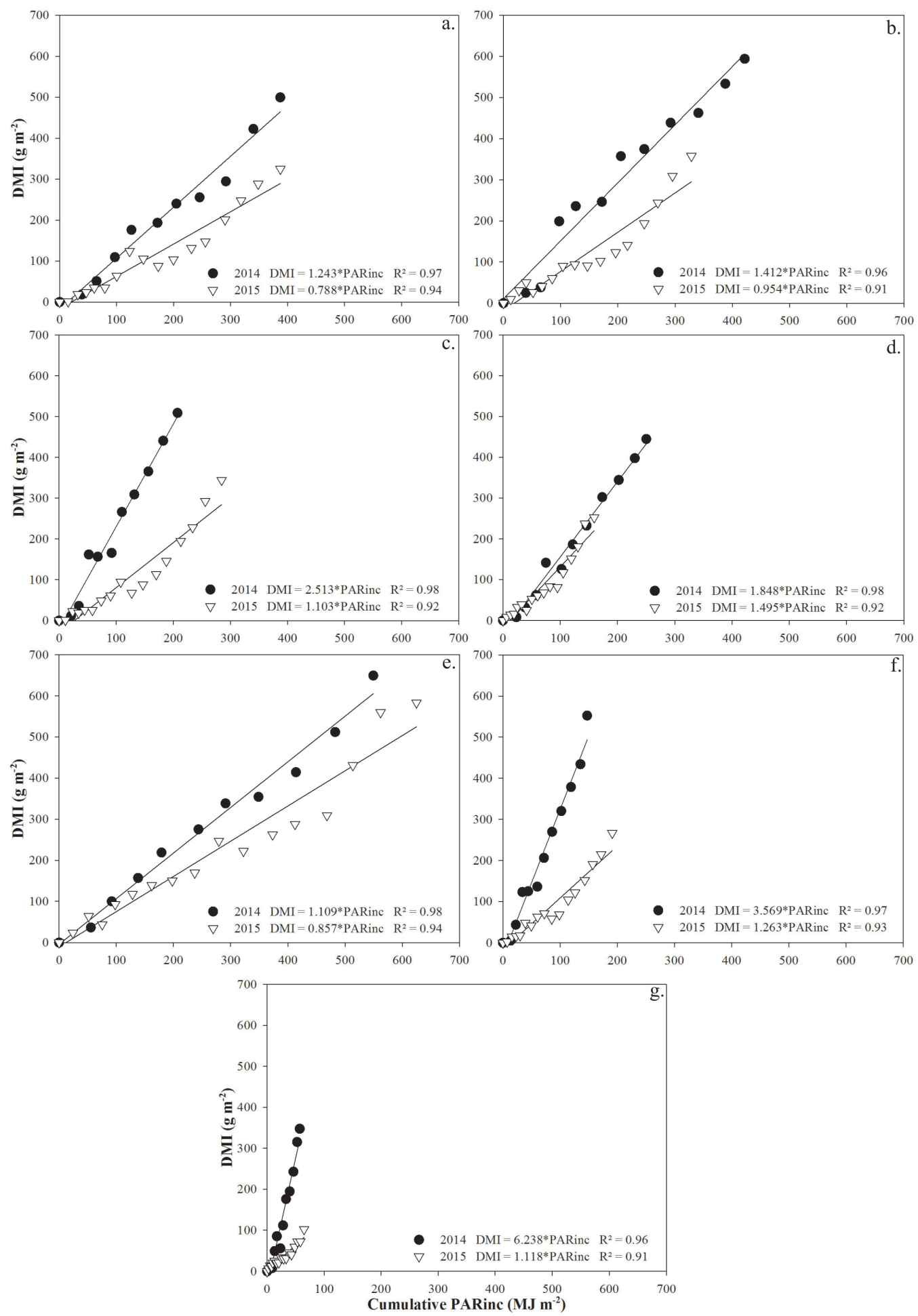

Figure 8 - Efficiency of the use of radiation $\left(\varepsilon b ; \mathrm{g} \mathrm{MJ}^{-1}\right)$ dual-purpose wheat cultivated in different cropping systems and with or without a cut (grazing simulation) in the crop years of 2014 and 2015 (Crop Seasons I and II, respectively). Dry matter increment (DMI); PARinc: Incident photosynthetically active radiation. S.parahyba Intercrop-I (a); P.rigida Intercrop-I (b); P.dubium Intercrop-I (c); and P.dubium Intercrop-II (d); Monoculture (e); Eucalyptus Intercrop-II (f); and Eucalyptus Intercrop-I (g). 
Influenced by the low availability of solar radiation, the phyllochron of wheat was reduced, reflecting in lower dry matter yield and grain yields; however, such losses can be compensated by the reduction of animal load during grazing or the pruning or thinning of the forest component which would further facilitate the transmission of solar radiation. The dual-purpose wheat crop has been shown to be highly plastic in response to its growth environment. Changes to the production microclimate, mainly solar radiation flux, air temperature, and relative air humidity, caused by the forest component, showed were strongly associated with changes in the growth and development of wheat plants when grown in shaded environments.

In spite of the lower conversion efficiency of solar radiation in wheat dry matter, the systems composed by S.parahyba Intercrop-I and P.rigida Intercrop-I provided a lower phyllochron for wheat and, therefore, a higher leaf area index and dry matter yield compared to other agroforestry systems.

This first work carried out in Brazil provides valuable responses for the growth and productivity of dual-purpose wheat in normal field planting conditions compared to the different shading levels generated in the agroforestry systems, and may help future researchers and applications in latitudes and tropical longitudes. The combination of forest species and agricultural crops well suited to each agroforestry system offers a promising alternative for integrating wood production as well as biomass for grazing animals and, in parallel, reinforces fertility through the positive effects of fixing of nitrogen and soil structuring. Additional research should be conducted in the quest to monitor tree productivity, to consider the economic value of agroforestry systems, and to measure forage production generated by crops grown in the understory in agroforestry systems.

\section{ACKNOWLEDGMENTS}

The authors wish to acknowledge the Conselho Nacional de Desenvolvimento Científico e Tecnológico (CNPq-Brazil), for the productivity scholarship and the Coordenação de Aperfeiçoamento de Pessoal de Nível Superior (Capes-Brazil) for their financial support.

\section{AUTHOR CONTRIBUTIONS}

BOC, CK and MVMP: Organization and planning of treatments, development of the written part of the work. FS, EFE, JS and LBT: project development, maintenance and conduct.

\section{REFERENCES}

ALBERTO CM, STRECK NAL, WALTER LC, ROSA HT, MENEZES NL AND HELDWEIN EAB. 2010. Modelagem do desenvolvimento de trigo considerando diferentes temperaturas cardinais e métodos de cálculo da função de resposta à temperatura. Pesqui Agropecu Bras 44: 545-553.

ALBRECHT AAND KANDJI ST. 2003. Carbon sequestration in tropical agroforestry systems. Agric Ecosyst Environ 99: 15-27.

ARTRU S, GARRÉ S, DUPRAZ C, HIEL M-P, BLITZFRAYRET C AND LASSOIS L. 2017. Impact of spatiotemporal shade dynamics on wheat growth and yield, perspectives for temperate agroforestry. Eur J Agron 82: 60-70.

BAHAMONDE HA, PERI PL AND MAYO JP. 2014. Modelo de simulación de producción de materia seca y concentración de proteína bruta de gramíneas creciendo en bosques de Nothofagus antarctica (G. Forster) Oerst. bajo uso silvopastoril. Ecol Austral 24: 111-117.

BARRO RS, SAIBRO JC, MEDEIROS RB, SILVA JLS AND VARELLA AC. 2008. Rendimento de forragem e valor nutritivo de gramíneas anuais de estação fria submetidas a sombreamento por Pinus elliottii e ao sol pleno. R Bras Zootec 37: 1721-1727.

BARTMEYER TN, DITTRICH JR, DA SILVA HA, DE MORAES A, PIAZZETTA RG, GAZDA TL AND CARVALHO PCF. 2011. Trigo de duplo propósito submetido ao pastejo de bovinos nos Campos Gerais do Paraná. Pesqui Agropecu Bras 46: 1247-1253.

BUNDCHEN M, BOEGER MRT AND REISSMANN CB. 2015. Estrutura foliar de espécies lenhosas de dossel e 
sub-bosque em uma floresta subtropical do sul do Brasil. Iheringia Sér Bot 70: 105-114.

CARDINAEL R, CHEVALLIER T, CAMBOU A, BÉRAL C, BARTHÈS BG, DUPRAZ C, DURAND C, KOUAKOUA E AND CHENU C. 2017. Increased soil organic carbon stocks under agroforestry: A survey of six different sites in France. Agric Ecosyst Environ 236: 243-255.

CARON BO, SOUZA VQ, TREVISAN R, BEHLING A, SCHMIDT D, BAMBERG R AND ELOY E. 2012. Eficiência de conversão da radiação fotossinteticamente ativa interceptada em fitomassa de mudas de eucalipto. Rev Arvore 36: 833-842.

CASAS RR, VARGAS P, PÉREZ-CORONA E, MANRIQUE E, GARCÍA-VERDUGO C AND BALAGUER L. 2011. Sun and shade leaves of Olea europaea respond differently to plant size, light availability and genetic variation. Funct Ecol 25: 802-812.

CUBILLOS AM, VALLEJO VE, ARBELI Z, TERÁN W, DICK RP, MOLINA CH, MOLINA E AND ROLDAN F. 2016. Effect of the conversion of conventional pasture to intensive silvopastoral systems on edaphic bacterial and ammonia oxidizer communities in Colombia. Eur J Soil Biol 72: 42-50.

CUNHA, NG DA, SILVEIRA RJC, KOESTER E, OLIVEIRA LD, ALBA JMF, TERRES VC AND LOPES RT. 2011. Estudos de Solos do Município de Frederico Westphalen, RS. Pelotas: Embrapa Clima Temperado, Circular Técnica 116, p. 32. Available in: <http://ainfo.cnptia. embrapa.br/digital/bitstream/item/45561/1/CIRCULARTECNICA-116.pdf>. Acessed 8 Jan 2016.

DRECHMER PAO AND RICIERI RP. 2006. Irradiação global, direta e difusa, para a região de Cascavel, Estado do Paraná. Acta Sci-Technol 28: 73-77.

ELLI EF, CARON BO, ELOY E, BEHLING A, SOUZA VQ AND SCHWERZ F. 2016. Productive, morphological and qualitive characteristics of sugarcane in the understory tree species in agroforestry systems. Afr J Agric Res 11: 15761584.

FAGUNDES JL, SILVA SC, PEDREIRA CGS, SBRISSIA AF, CARNEVALLI RA, CARVALHO CAB AND PINTO LFM. 1999. Índice de área foliar, interceptação luminosa e acúmulo de forragem em pastagens de Cynodon spp. Sob diferentes intensidades de pastejo. Sci Agr 56: 1141-1150.

FERREIRO-DOMÍNGUEZ N, NAIR VD AND FREESE D. 2016. Phosphorous dynamics in poplar silvopastoral systems fertilised with sewage sludge. Agric Ecosyst Environ 223: 87-98.

FIOREZE SL AND RODRIGUES JD. 2014. Componentes produtivos do trigo afetados pela densidade de semeadura e aplicação de regulador vegetal. Semina: Ciênc Agrár 35: 39-53.
GILMORE JUNIOR EC AND ROGERS JS. 1958. Heat units as a method of measuring maturity in corn. Agron J 50: 611-615.

HAUN JR. 1973. Visual quantification of wheat development. Agron J 65: 116-119.

JOHNSON D AND SMITH W. 2006. Low clouds and cloud immersion enhance photosynthesis in understory species of a southern Appalachian spruce-fir forest (USA). Am J Bot 93: 1625-1632.

LARGE EC. 1954. Growth stages in cereals illustration of the Feeks scales. Plant Pathol 4: 22-24.

LÓPEZ-DÍAZ ML, BENÍTEZ R AND MORENO G. 2017. How do management techniques affect carbon stock in intensive hardwood plantations? For Ecol Manage 389: 228-239.

LUNAGARIA MM AND SHEKH AM. 2006. Radiation interception, light extinction coefficient and leaf area index of wheat (Triticum aestivum L.) crop as influenced by row orientation and row spacing. J Agric Sci 2: 43-54.

MARIN AMP, MENEZES RSC, SILVA ED AND SAMPAIO EVSB. 2006. Efeito da Gliricidia sepium sobre nutrientes do solo, microclima e produtividade do milho em sistema agroflorestal no Agreste Paraibano. Rev Bras Cienc Solo 30: 555-564.

MEINERZ GR, OLIVO CJ, FONTANELI RS, AGNOLIN CA, HORST T AND BEM CMD. 2012. Produtividade de cereais de inverno de duplo propósito na depressão central do Rio Grande do Sul. R Bras Zootec 41: 873-882.

MENEZES RSC, SALCEDO IH AND ELLIOTT ET. 2002. Microclimate and nutrient dynamics in a silvopastoral system of semiarid northeastern Brazil. Agrofor Syst 56: 27-38.

MIELKE MS AND SCHAFFER B. 2010. Photosynthetic and growth responses of Eugenia uniflora L. seedlings to soil flooding and light intensity. Environ Exp Bot 68:113-121.

MONTEITH JL AND MOSS CJ. 1977. Climate and the efficiency of crop production in Britain. Philosophical Transactions of the Royal Society of London. B, Biol Sci 281: 277-294.

MÜLLER MD, PACIULLO DSC, MARTINS CE, ROCHA WSD AND CASTRO CRT. 2014. Desenvolvimento vegetativo de pinhão-manso em diferentes arranjos de plantio em sistemas agrossilvipastoris. Pesq Agropec Bras 49: 506-514.

NAIR PKR, GORDON AM AND MOSQUERA-LOSADA MR. 2008. Agroforestry. Ency Ecol 1: 101-110.

PEZZOPANE JRM, BOSI C, NICODEMO MLF, SANTOS PM, CRUZ PGD AND PARMEJIANI RS. 2015. Microclimate and soil moisture in a silvopastoral system in southeastern Brazil. Bragantia 74: 110-119.

QUINKENSTEIN A, WÖLLECKE J, BÖHM C, GRÜNEWALD H, FREESE D, SCHNEIDER BU AND HÜTTL RF. 2009. Ecological benefits of the alley 
cropping agroforestry system in sensitive regions of Europe. Environ Sci Pol 12: 1112-1121.

REYNOLDS PE, SIMPSON JA, THEVATHASAN NV AND GORDON AM. 2007. Effects of tree competition on corn and soybean photosynthesis, growth, and yield in a temperate tree-based agroforestry intercropping system in southern Ontario, Canada. Ecol Eng 29: 362-371.

RIGHI CA, BERNARDES MS, LUNZ AMP, PEREIRA CR, NETO DD AND FAVARIN JL. 2007. Measurement and simulation of solar radiation availability in relation to the growth of coffee plants in an agroforestry system with rubber trees. Rev Arvore 31: 195-207.

RIVEST D, LORENTE M, OLIVIER A AND MESSIER C. 2013. Soil biochemical properties and microbial resilience in agroforestry systems: effects on wheat growth under controlled drought and flooding conditions. Sci Total Environ 463-464: 51-60.

SANCHEZ PA. 1995. Science in agroforestry. Agrofor Syst 30: 5-55.

SANTOS HP, FONTANELI RS, CASTRO RLD, VERDI AC, VARGAS AM AND BIAZUS V. 2015. Avaliação de trigo para grãos e duplo propósito, sob plantio direto. Rev Bras Cienc Agra 10: 43-48.

STRECK NA, PAULA FLM, BISOGNIN DA, HELDWEIN AB AND DELLAI J. 2007. Simulating the development of field grown potato (Solanum tuberosum L.). Agric For Meteorol 142: 1-11.

TORRALBA M, FAGERHOLM N, BURGESS PJ, MORENO G AND PLIENINGER T. 2016. Do European agroforestry systems enhance biodiversity and ecosystem services? A meta-analysis. Agric Ecosyst Environ 230: 150-161.

VALENTINI LSP, CAMARGO MBP, ROLIM GS, SOUZA PS AND GALLO PB. 2010. Temperatura do ar em sistemas de produção de café arábica em monocultivo e arborizados com seringueira e coqueiro-anão na região de Mococa, SP. Bragantia 69: 1005-1010.

VARLET-GRANCHER C, GOSSE G, CHARTIER M, SINOQUET H, BONHOMME R AND ALLIRAND JM. 1989. Mise au point: rayonnement solaire absorbé ou intercepté par un couvert végétal. Agronomie 9: 419-439.

VOISIN A. 1957. Productivité de l'herbe. Paris: Flammarion, $457 \mathrm{p}$.

WANG Q, HAN S, ZHANG L, ZHANG D, VAN DER WERF W, EVERS JB, SUN H, SU Z AND ZHANG S. 2016. Density responses and spatial distribution of cotton yield and yield components in jujube (Zizyphus jujube)/cotton (Gossypium hirsutum) agroforestry. Eur J Agron 79: 5865.

WANG Y, GUO Q AND JIN M. 2009. Effects of light intensity on growth and photosynthetic characteristics of Chrysanthemum morifolium. Zhong Zhong Zaz 34: 1633 1635.

WILHELM WW AND MCMASTER GS. 1995. Importance of the phyllochron in studying development and growth in grasses. Crop Sci 35: 1-3.

YIN X, GOUDRIAAN J, LANTINGA EA, VOS J AND SPIERTZ HJ. 2003. A flexible sigmoid function of determinate growth. Ann Bot 91: 361-371.

XUE QW, WEISS A AND BAENZIGER PS. 2004. Predicting leaf appearance in field-grown winter wheat: evaluating linear and non-linear models. Ecol Modell 175: 261-270.

YOSHIDA S, MANDEL T AND KUHLEMEIER C. 2011. Stem cell activation by light guides plant organogenesis. Genes Dev 25: 1439-1450.

ZHANG W, AHANBIEKE P, WANG BJ, XU WL, LI LH, CHRISTIE P AND LI L. 2013. Root distribution and interactions in jujube tree/wheat agroforestry system. Agrofor Syst 87: 929-939. 